\title{
Deteksi Kejenuhan Seluruh Otot Manusia Menggunakan Sensor EMG Berbasis Mikrokontroler Arduino UNO
}

\author{
${ }^{1}$ Firdhan Tri Abyanto*), ${ }^{1}$ Florentinus Budi Setiawan \\ 1 Teknik Elektro, Universitas Katolik Soegijapranata
}

firdhan.triabyanto@gmail.com*)

\begin{abstract}
Abstrak
Pada perkembangan zaman yang pesat ini di butuhkan suatu peralatan medis yang modern, maka pada peper ini menjelaskan tentang Electromyography (EMG) dimana untuk mendeteksi listrik yang ada di dalam otot manusia. Untuk adanya suatu aktivitas listrik pada suatu otot manusia dilakukan analisis terhadap rangkaian penguat sinyal. Sinyal ini mempunyai suatu amplituda yang sangat kecil maka dibutuhkan suatu komponen yaitu elektroda gel sebagai media untuk mendeteksi sinyal otot tersebut. Elektroda di tempelkan ke bagian otot yang ingin di ukur. Kemudian sinyal dikuatkan dengan menggunakan rangkaian AD620AN dengan 500 kali penguatan dan komparator pada penggunannya di aplikasikan dalam mode Inverting dan Buffer. Dalam pengkondisian sinyal dibuat rangkaian Low Pass Filter dengan envelope detector untuk merata rata sinyal otot yang dikeluarkan menjadi tegangan DC. Pada paper ini membahas tentang aplikasi alat EMG yang berfungsi sebagai pengukur tegangan seluruh otot untuk mendeteksi otot dalam keadaan tegang dan relaksasi dengan bantuan mikrokontroler. Pada output sinyal EMG kemudian menuju ke ADC lalu ke mikrokontroler Arduino uno.
\end{abstract}

Kata Kunci: electromyography, Otot manusia, rectifier, amplifier, arduino uno.

\section{Pendahuluan}

Dalam aktivitas sehari - hari, otot memiliki peranan yang sangat penting untuk menunjang proses kegiatan manusia. Semua aktivitas yang dilakukan manusia menggunakan otot, seperti makan, minum, mandi, berjalan, bahkan tidur. Apabila otot tidak bekerja secara maksimal, maka aktivitas sudah pasti akan terganggu [1][2].

Otot adalah sebuah jaringan konektif dalam tubuh dengan tugas utamanya kontraksi. Kontraksi otot berfungsi untuk menggerakkan bagian-bagian tubuh dan substansi dalam tubuh. Ada tiga macam sel otot dalam tubuh manusia yaitu: jantung, lurik dan polos, namun yang berperan dalam pergerakan kerangka tubuh manusia adalah otot lurik (otot rangka). Kelelahan otot adalah penurunan kemampuan otot untuk menciptakan kekuatan, berkontraksi dan gaya yang dihasilkan berkurang. Elektromiografi (EMG) adalah teknik medis untuk mengukur respon otot terhadap stimulasi syaraf selama otot berkontraksi, power spectrum EMG bergeser ke arah frekuensi yang lebih rendah, efek ini disebabkan oleh kelelahan otot. Kelelahan otot sering merupakan hasil dari kerja otot yang tidak sehat. Tidak seperti evaluasi khas subjektif, yang biasanya menentukan titik waktu ketika subjek tidak dapat lagi menjalankan tugas, analisis sinyal EMG dapat memberikan informasi pengukuran metabolisme kontinyu di seluruh bagian 2 otot yang menunjukkan kelelahan selama kontraksi. Namun, ambang batas kelelahan otot tidak dapat didefinisikan sebagai fungsi sederhana dari besarnya beban otot dan timing, karena karakteristik dan kemampuan otot bervariasi pada setiap individu [1][2].

Dalam rencana desain pembuatan alat ini, sensor yang digunakan adalah sensor EMG untuk mendeteksi sinyal kejenuhan seluruh otot yang sedang bekerja, dari sinyal output EMG maka akan di clamping terlebih dahulu sebelum masuk ke dalam ADC lalu ke mikrokontroler Arduino uno untuk mengirim data digital ke LCD. kemudian sinyal ini dikuatkan oleh AD620 dan dilewatkan ke filter untuk mendapatkan hasil sinyal yang diperlukan dan menggunakan output LCD dan voltmeter tersebut berfungsi untuk mengecek presentase baterai 1 dan baterai 2. Berikut blok diagram dari perancangan system.

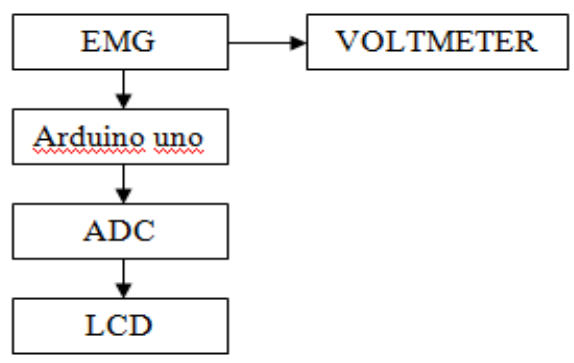

Gambar 1. Blok Diagram Perancangan Alat. 


\subsection{EMG (Electromyography)}

EMG adalah teknik untuk memeriksa dan merekam aktivitas sinyal otot. Pengukuran sinyal EMG dilakukan dengan instrument bernama elektromiograf, dan sedangkan hasil rekamannya dinamakan elektromiogram. Elektromiograf mendeteksi listrik yang dihasilkan otot ketika otot ini aktif dan non aktif. Dan untuk menghasilkan suatu sinyal EMG dimana otot akan mengalami tahapan yaitu membrane potensial, muscle fiber action potensial ditambah noise dan artifact sehingga menghasilkan suatu kumpulan yang disebut MUAP (Motor Unit Action Potential) [4][6] [7][8][9].

\subsection{Elektroda}

Pada pengukuran ini peran yang sangat penting yaitu elektroda, karena dimana pertama masuknya sinyal otot yang akan dibaca oleh alat ini, fungsi dari komponen ini sebagai penghantar sinyal untuk mengirimkan sinyal ke tubuh yaitu dengan cara ditempelkan.

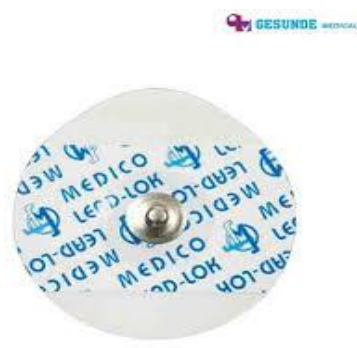

Gambar 2. Elektroda Perak Klorida dengan Gel

\subsection{OP AMP}

OP AMP merupakan penguat sinyal masukan baik DC maupun AC juga sebagai penguat diferensiasi impedansi masukan tinggi dan penguat keluaran impedansi rendah [2] [4].

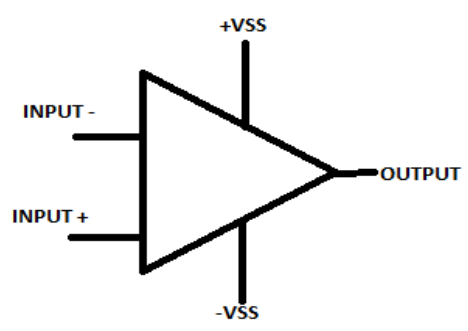

Gambar 3. Penguat Operasional

\section{Perancangan Alat}

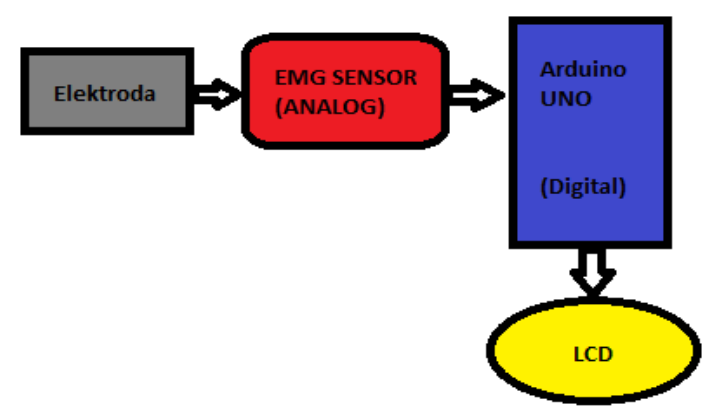

Gambar 4. Diagram Blok Alur Sinyal EMG

Pada gambar diatas terdapat blok diagram alur sinyal EMG yang dimana dibagi menjadi 2 bagian yaitu bagian rangkaian analog dan rangkaian digital.

\subsection{Rangkaian Analog}

Pada rangkaian ini EMG sensor di fungsikan sebagai rangkaian analog. Pada rangkaian analog ini terdapat sebuah komponen yaitu AD260 AN yang berfungsi sebagai penguat sinyal dan TL062 sebagai inverting dan buffer, serta alat ini memiliki rangkaian envelope detector sebagai filter.

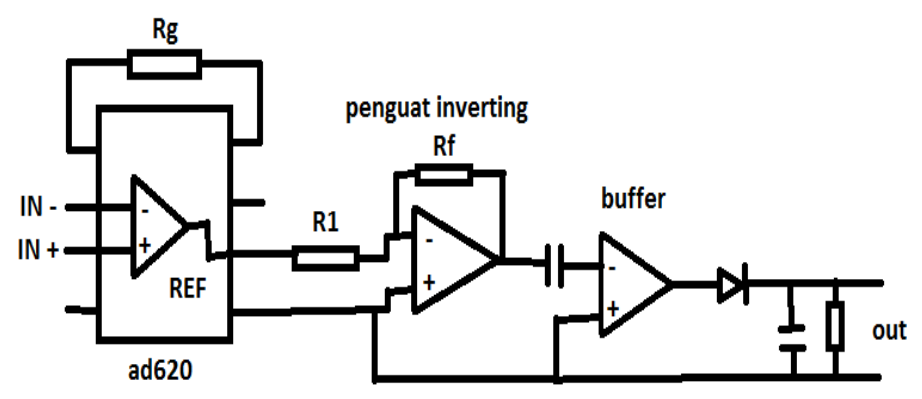

Gambar 5. Rangkaian EMG

\subsubsection{AD 620AN}

AD 620AN ini merupakan IC yang sering digunakan pada aplikasi pembacaan sinyal EMG dan berfungsi sebagai memperkuat sinyal dan komponen ini memiliki kelebihan tidak rentan terhadap suatu noise, butuh daya yang rendah dan hanya menggunakan satu resistor untuk mengatur penguatannya. Terdapat sebuah rumus untuk menentukan nilai resistor yang digunakan dan penguatan yang dihasilkan [5][10]. 


$$
R_{G}=\frac{49.4 k \Omega}{G-1}
$$

Keterangan :

$R G=$ Nilai Resistor yang ingin digunakan .

$G=$ Nilai penguatan yang di inginkan.

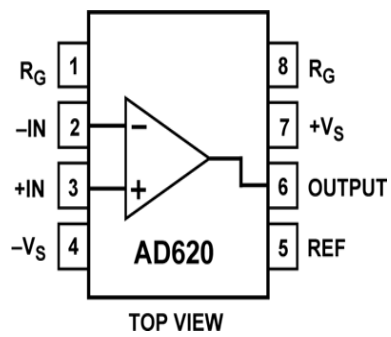

Gambar 6. AD 620AN

\subsubsection{Dual op-amp TL062}

Dalam aplikasi ini IC yang digunakan yaitu sebuah IC TL062, IC ini digunakan dalam mode inverting dan buffer. Pada mode inverting tujuannya untuk mengatur penguatan sinyal dari AD 620AN dan pada mode buffer yang bersamaan dengan diode dan envelope detector tujuannya untuk menyearahkan sinyal keluaran yang telah dikuatkan sebelumnya [4].

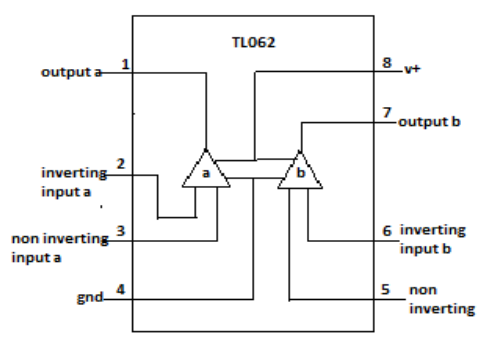

Gambar 7. IC TL062

\subsubsection{Envelope detector}

Envelope detector yaitu memiliki tujuan untuk mempertahankan nilai puncak yang dikeluarkan pada tahap pengutan sebelumnya. Pada envelope detector memiliki 3 buah komponen yaitu terdiri dari dioda, capasitor dan resistor [4].

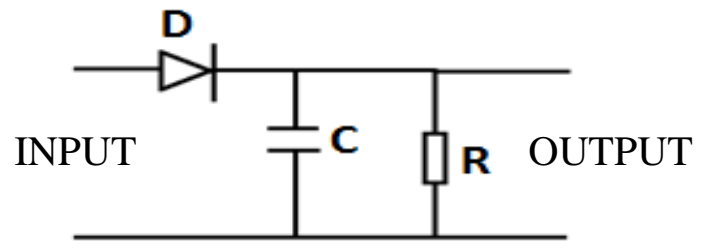

Gambar 8. Rangkaian Envelope Detector

\subsection{Rangkaian digital}

Pada sebuah rangkaian digital menggunakan mikrokontroler Arduino, sebuah board mikrokontroller yang berbasis ATmega328. Arduino memiliki 14 pin input/output yang mana 6 pin dapat digunakan sebagai output PWM, 6 analog input, crystal osilator $16 \mathrm{MHz}$, koneksi USB, jack power, kepala ICSP, dan tombol reset. Arduino mampu men-support mikrokontroler; dapat dikoneksikan dengan komputer menggunakan kabel USB [3].

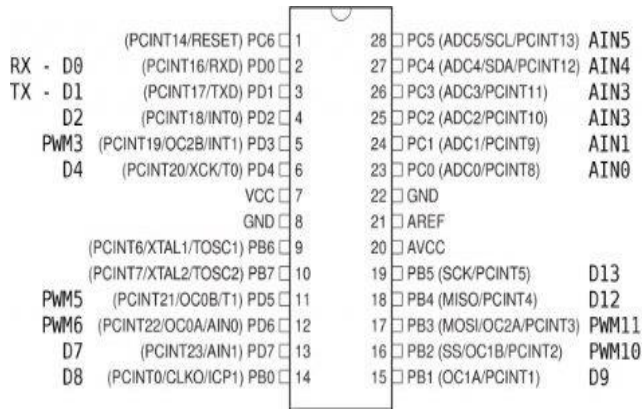

Gambar 9. Konfigurasi Pin Arduino Uno Berbasis ATmega328

\section{Hasil Pengujian dan Analisa}

Dibawah ini adalah hasil pengukuran otot dalam keadaan relaksasi serta otot dalam keadaan kontraksi dengan hasil tegangan yang berbeda-beda pada setiap otot, dari 10 titik otot yang berbeda berdasarkan orang yang sama.

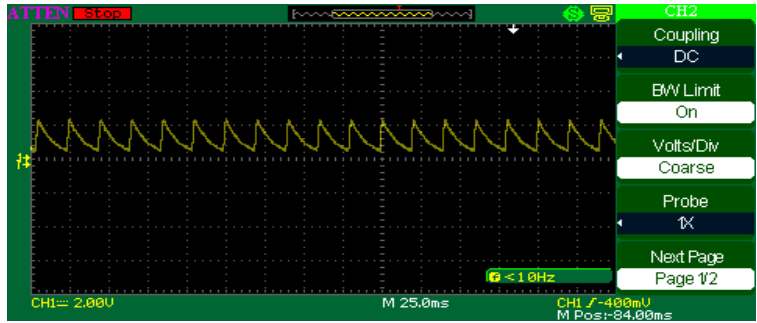

Gambar 10. Otot Trapezius Saat Relaksasi Bernilai $1140 \mathrm{mV}$ 


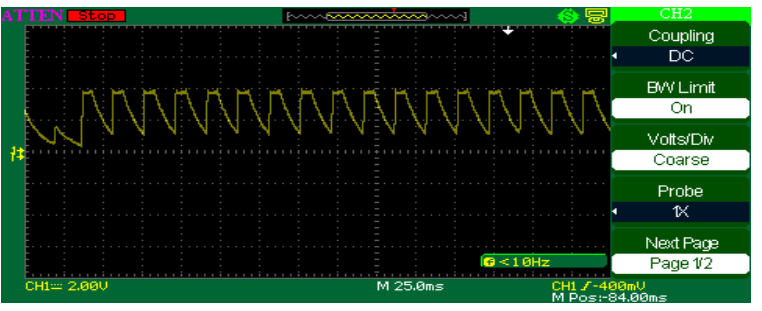

Gambar 11. Otot Trapezius Saat Kontraksi Bernilai $3430 \mathrm{mV}$

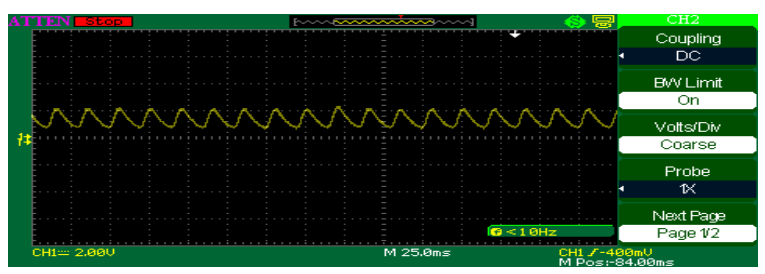

Gambar 12. Otot Pectoralis Major Saat Relaksasi Bernilai $960 \mathrm{mV}$

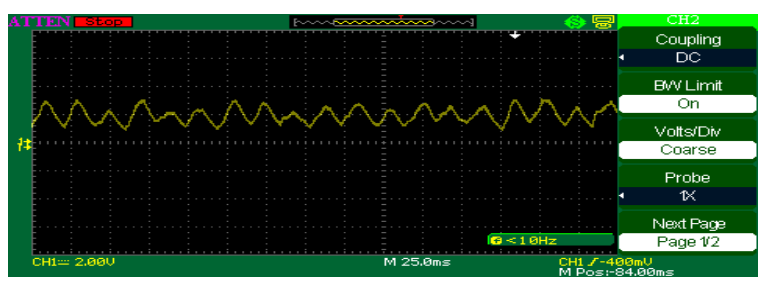

Gambar 13. Otot Pectoralis Major Saat Kontraksi Bernilai $1237 \mathrm{mV}$

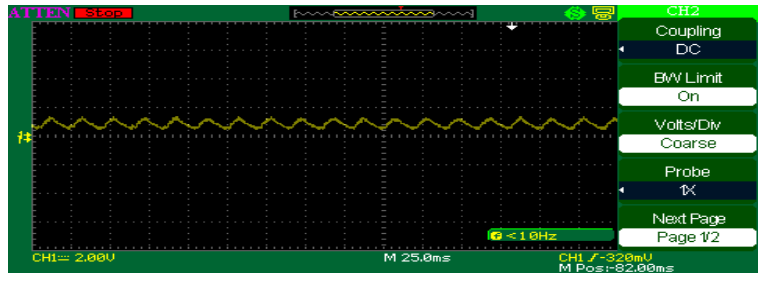

Gambar 14. Otot Deltoid Saat Relaksasi Bernilai 170 $\mathrm{mV}$

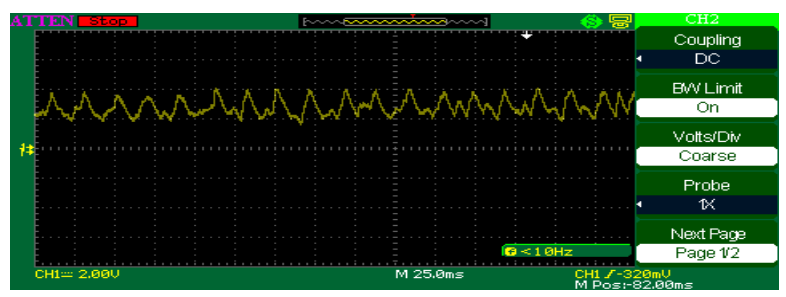

Gambar 15. Otot Deltoid Saat Kontraksi Bernilai 1800 $\mathrm{mV}$

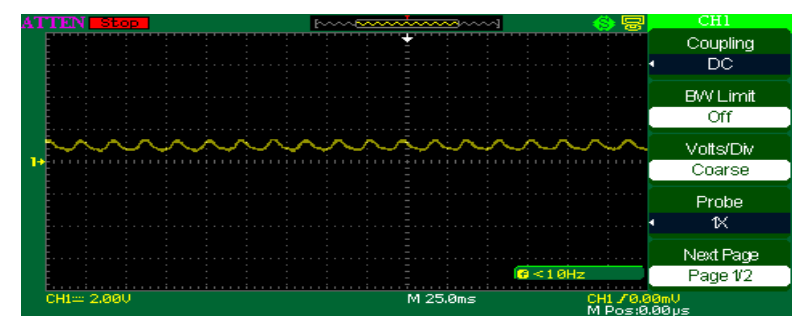

Gambar 16. Otot Platysma Saat Relaksasi Bernilai $940 \mathrm{mV}$

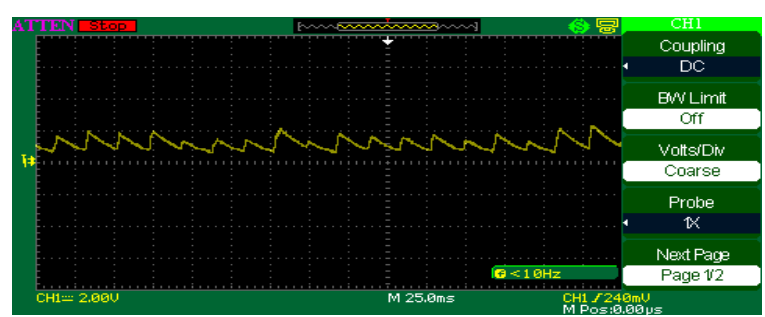

Gambar 17. Otot Platysma Saat Kontraksi Bernilai $1740 \mathrm{mV}$

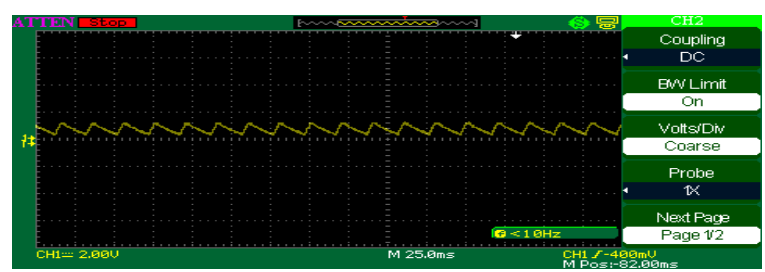

Gambar 18. Otot Brachioradialis Saat Relaksasi Bernilai $480 \mathrm{mV}$

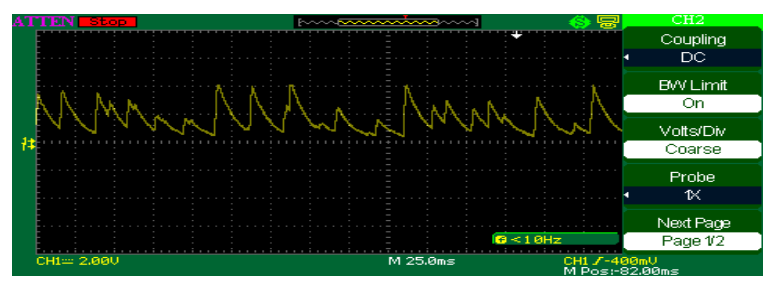

Gambar 19. Otot Brachioradialis Saat Kontraksi Bernilai $2180 \mathrm{mV}$

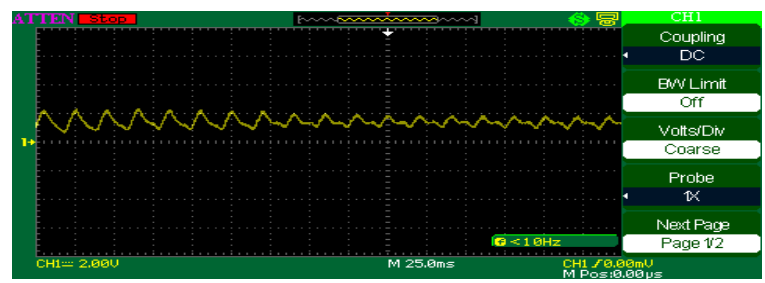

Gambar 20. Otot Latissimus Dorsi Saat Relaksasi Bernilai $500 \mathrm{mV}$

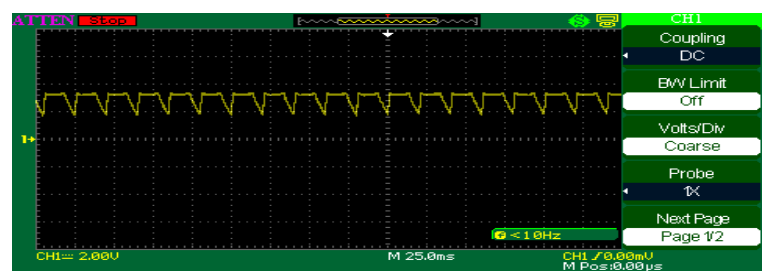

Gambar 21. Otot Latissimus Dorsi Saat Kontraksi Bernilai $3320 \mathrm{mV}$

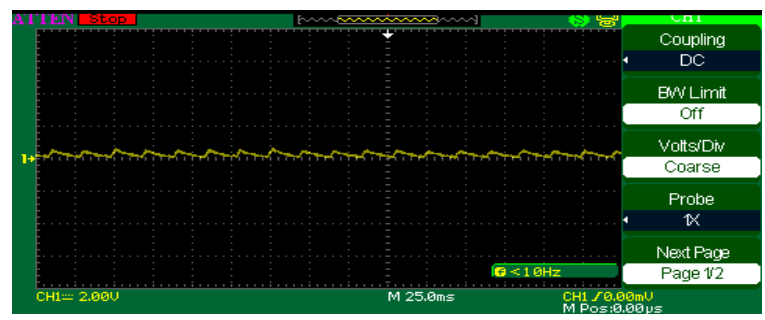

Gambar 22. Otot Rhomboid Saat Relaksasi Bernilai $830 \mathrm{mV}$ 


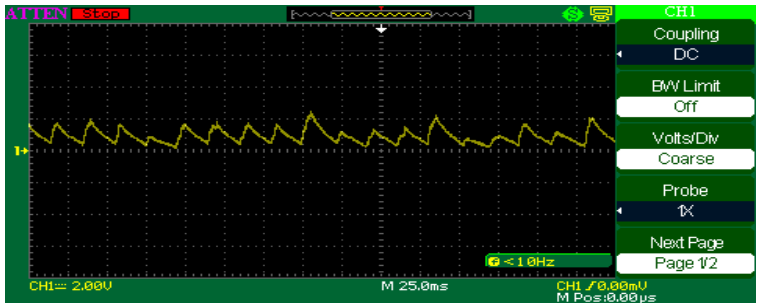

Gambar 23. Otot Rhomboid Saat Kontraksi Bernilai $2180 \mathrm{mV}$

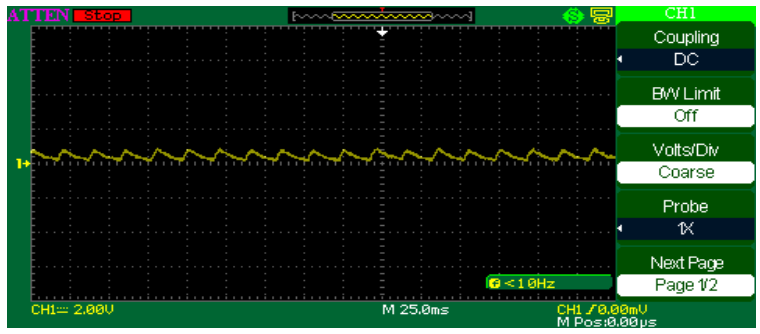

Gambar 24. Otot Serratus Anterior Saat Relaksasi Bernilai $800 \mathrm{mV}$

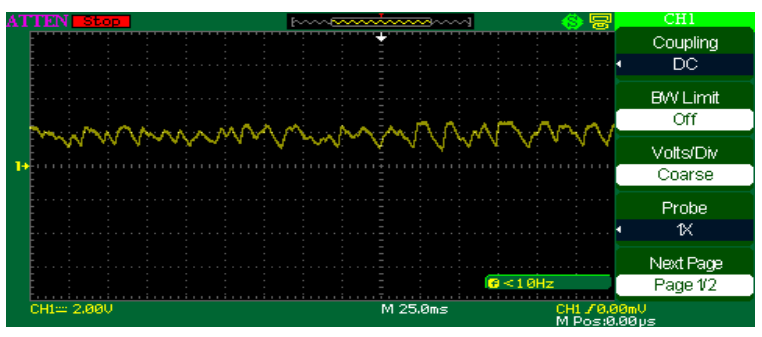

Gambar 25. Otot Serratus Anterior Saat Kontraksi Bernilai $2440 \mathrm{mV}$

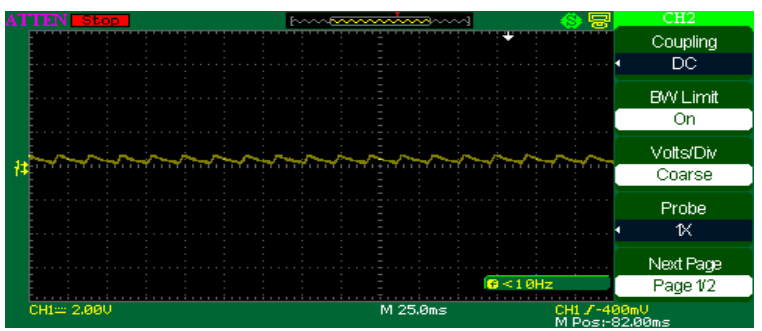

Gambar 26. Otot Extensor Carpi Ulnaris Saat Relaksasi Bernilai $740 \mathrm{mV}$

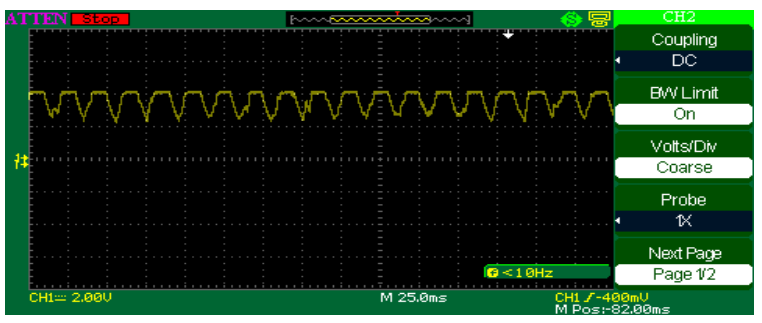

Gambar 27. Otot Extensor Carpi UInaris Saat Kontraksi Bernilai 3970 mV

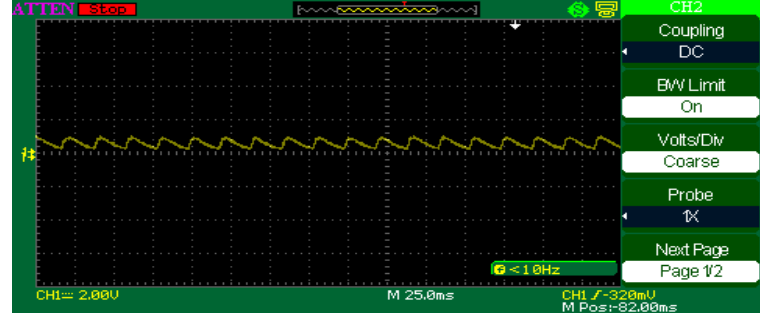

Gambar 28. Otot Trisep Saat Relaksasi Bernilai 890 $\mathrm{mV}$

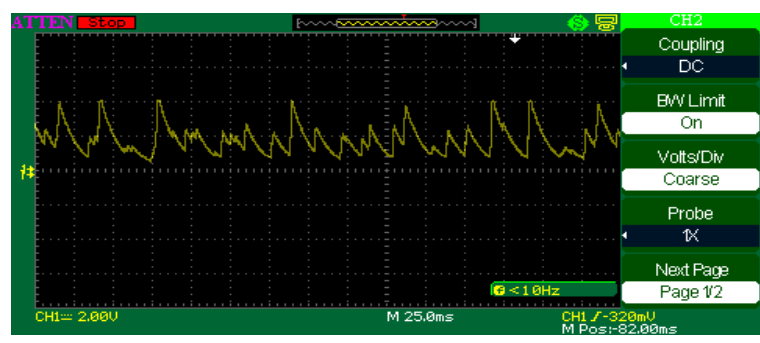

Gambar 29. Otot Trisep Saat Kontraksi Bernilai 2530 $\mathrm{mV}$

\section{Kesimpulan}

Penulis melakukan pengukuran pada 10 titik otot yang berbeda tetapi dalam satu orang yang sama, dimana nantinya terdapat hasil pengukuran tegangan otot yang berbeda-beda. Sinyal dikuatkan dengan menggunakan rangkaian AD620AN berfungsi sebagai penguat dalam aplikasi EMG dan komparator (TL062) pada penggunannya di aplikasikan dalam mode Inverting dan Buffer, komparator di pasang dalam mode inverting, tujuannya sebagai penguat sinyal, kemudian sinyal di masukkan ke Buffer Amplifier yang di beri dioda dan Envelope Detector pada keluarannya, Tujuan dari proses penyearahan dan pemfilteran adalah untuk merata-rata sinyal otot yang telah di kuatkan menjadi sinyal DC yang kemudian dapat di baca oleh ADC mikrokontroler Arduino uno/ATmega 328. Sample nilai keluaran yang didapat yaitu ketika otot dalam keadaan relaksasi bernilai $100 \mathrm{mV}$ dan ketika otot keadaan kontraksi bernilai $5000 \mathrm{mV}$. Jadi pada penelitian ini pada pengukuran otot tidak bisa diukur asal-asalan dan harus mengetahui keberadaan titik otot terlebih dahulu pada seluruh bagian tubuh.

\section{Daftar Pustaka}

[1] Rizki Multajam dan Mada Sanjaya, "DESAIN DAN ANALISIS ELECTROMYOGRAPHY (EMG) SERTA APLIKASINYA DALAM MENDETEKSI SINYAL OTOT", ALHAZEN Journal of Physics, Vol. 2, No. 2, 2016. 
[2] Yohanes Oxa Wijaya, Florentinus Budi Setiawan, Siswanto, "Desain dan Implementasi Alat Pengukur Ketegangan Otot", Industrial Research Workshop and National Seminar, 2014.

[3] Ai Fitri Silvia, Erik Haritman, Yuda Muladi, "RANCANG BANGUN AKSES KONTROL PINTU GERBANG BERBASIS ARDUINO DAN ANDROID”, ELECTRANS, VOL.13, N0.1, 2014.

[4] Ricky Fajar Adiputra, Florentinus Budi Setiawan, "ROBOT ARM CONTROLLED BY MUSCLE TENSION BASED ON ELECTROMYOGRAPHY AND PIC18F4550", Int. Conf. on Information Tech., Computer and Electrical Engineering (ICITACEE), Oct 19-21st, 2016.

[5] Fitri Rohmaisa, Endah Rahmawati dan Imam Sucahyo, "RANCANG BANGUN ALAT ELEKTROKARDIOGRAF LEAD 1 BERBASIS SOUNDCARD PADA KOMPUTER", Jurnal Inovasi Fisika Indonesia, Vol. 04, No 03, 2015.

[6] Gregory S. Rash, EdD. Electromyography Fundamentals.

[7] Konrad,Peter. The ABC of EMG : A Practical Introduction to Kinesiological Electromyography. April 2005.

[8] Florentinus Budi Setiawan, siswanto, "Electromyography (EMG) Signal Compression using Sinusoidal Segmental Model", ", Int.I Conference on Information Technology, Computer and Electrical Engineering (ICITACEE), 2015.

[9] Kevin Eka Pramudita, F Budi Setiawan, Siswanto, "Interface and display of Electromyography signal wireless measurements", International Conference on Information Technology, Computer and Electrical Engineering (ICITACEE), 2014.

[10] Florentinus Budi Setiawan, Siswanto, "Multi Channel Electromyography (EMG) Signal Acqiusition using Microcontroller with Rectifier", Int. Conf. on Information Tech., Computer and Electrical Engineering (ICITACEE), Oct 19-21st, 2016.

[11] AD620 datasheet, Analog Device, 2010. 